Общая история Церкви. Учебное пособие для вузов

по специальности 030600.62 "История". В 2 т., 4 кн. Сост., отв. ред. В. В. Симонов. М.: Наука, 2017 (Труды исторического факультета МГУ: 78-81; Сер. II. Исторические исследования, 35-38).

Т. 1: От зарождения Церкви к Реформации: I-XV века. Кн. 1: Богословское и организационное становление Церкви: I-III века. 368 с. Кн. 2: Доктринальные вызовы Церкви: IV-XV века. 829 с. Т. 2: От Реформации к веку секулярной глобализации: XVI - начало XXI века. Кн. 1: Организационные вызовы Церкви: XVI - начало XX века. 538 с. Кн. 2: Вызов религиозного синкретизма: Проблема экуменизма: XX - начало XXI века. 511 с. ISBN: 978-5-02-039218-2.

Запальский Г. М. Московский государственный университет им. М.В.Ломоносова, исторический факультет, зам. заведующего кафедрой истории Церкви, доцент, кандидат исторических наук, SPIN-код: 7790-7557, ORCID: 0000-0002-5109-1032, e-mail: zapalsky@mail.ru

Российский журнал истории Церкви. 2020;1(1):11. doi:10.15829/2686-973X-2020-1-13

\title{
General history of the Church. Textbook for universities in the specialty 030600.62 "History". In 2 vols., 4 books. Comp., Ed. V. V. Simonov. Moscow: Nauka, 2017 (Writings of the historical faculty of Moscow State University: 78-81; Ser. II. Historical research, 35-38).
}

Vol. 1: From the birth of the Church to the Reformation: I-XV centuries. Book 1: Theological and organizational formation of the Church: I-III centuries. 368 p. Book 2: Doctrinal challenges of the Church: IV-XV centuries. 829 p. Vol. 2: From the Reformation to the age of secular globalization: XVI-beginning of the XXI century. Book 1: Organizational challenges of the Church: XVI - early XX century. 538 p. Book 2: The challenge of religious syncretism: The problem of ecumenism: XX - the beginning of the XXI century. 511 p. ISBN: 978-5-02-039218-2.

Gleb M. Zapalsky. M.V. Lomonosov Moscow State University, Historical faculty, Deputy head of the Department of Church History, Associate Professor, Dr. of historical sciences, SPIN-code: 7790-7557, ORCID: 0000-0002-51091032, e-mail: zapalsky@mail.ru Russian Journal of Church History. 2020;1(1):11. (In Russ.) doi:10.15829/2686-973X-2020-1-13 
Данное издание в четырех книгах является основной частью подготовленного кафедрой истории Церкви исторического факультета Московского государственного университета им. М.В.Ломоносова учебно-методического комплекса, предназначенного для студентов-историков. Это первое в отечественной литературе полное систематизированное изложение общей истории Церкви I-XXI вв.

Издание состоит из двух томов по две части (книги) в каждом. Первый том “От зарождения Церкви к Реформации: I-XV века" включает первую книгу "Богословское и организационное становление Церкви: I-III века" и вторую книгу “Доктринальные вызовы Церкви: IV-XV века”. Второй том "От Реформации к веку секулярной глобализации: XVI - начало XXI века" - книги "Организационные вызовы Церкви: XVI - начало XX века" и "Вызов религиозного синкретизма: Проблема экуменизма: XX - начало XXI века".

Прежде всего этот проект обеспечивает решение конкретных задач образовательного процесса: он предназначен для студентов бакалавриата исторического факультета, изучающих дисциплину “Общая история Церкви”, а также для студентов магистратуры, слушающих курс "История христианства в России”. Однако издание востребовано в других светских и конфессиональных вузах разных конфессий, где изучаются схожие дисциплины. Кроме того, проект адресован более широкой аудитории исследователей и всех интересующихся историей Церкви, поскольку в учебном пособии дается широкий и подробный обзор исторического развития института Церкви, хронологически охватывающий весь двухтысячелетний период ее существования. Изложение включает начальные этапы церковной истории, историю православия, католицизма, основных протестантских деноминаций, “ориентальных” (“дохалкидонских”) церквей (в т.ч. развернутое изложение истории Армянской апостольской церкви) и другое.

В состав авторского коллектива вошли сотрудники Кафедры истории Церкви В. В. Симонов (ответственный редактор и автор многих разделов), Г. М. Запальский, А. Г. Зоитакис, П. В. Кузенков, 3.Ю.Метлицкая, И. В. Поздеева, Л.Г. Хрушкова, Е.В.Белякова, а также К.А. Аветисян. Отдельные параграфы были написаны с использованием материалов Ю.С. Белянкина, Е.В. Гуваковой и Е.А. Заболотного. Ранее коллектив кафедры уже выпустил два пособия с обзором источников и обзором историографии общей истории Церкви.

Важная особенность издания - отказ от узкоконфессионального подхода в изложении истории Церкви. Авторы предлагают воспринимать историю Церкви в расширенном контексте, как историю совокупности христианских конфессий и деноминаций, считающихся Церковью в силу содержания вероучения и сложившейся институциональной структуры (епископальной или пресвитерианской), не делая акцент на проблеме качества изложения их вероучений. В учебном пособии отсутствует тенденциозность в описании межцерковных противоречий, неоднозначных исторических событий и личностей.

При этом авторский коллектив не отказывается от выяснения таких понятий, как ортодоксия и ересь, что позволяет включить в содержание 
книг не только развитие идеологически преобладающего мнения в тот или иной период, но и отклонения от него, с которыми связаны возникновение и специфика целого ряда явлений (раннехристианские ереси; народные движения на юге Европы, имевшие выраженный религиозный контекст; религиозный гуманизм, опиравшийся как на вполне ортодоксальное, так и на явно нестандартное понимание истин христианского учения; деноминационные особенности процесса Реформации и др.).

Институциональный подход к церковной структуре формирует представление о богатстве форм, которые принимало историческое христианство в разнящихся политических и социокультурных условиях. Отказ от доминирующего конфессионального стержня дает важное преимущество - возможность определить те факторы, которые формировали и продолжают влиять на внутреннее единство христианского мира вопреки догматическим расхождениям. Материал учебного пособия также дает возможность рассмотреть разные варианты вовлеченности Церкви в процессы становления национальных общностей, а в результате - по-новому оценить весь исторический путь Европы. Не отказываясь от традиционной дихотомии “восточное - западное христианство" или “восточноевропейская - западноевропейская культура", авторы демонстрируют множественность воздействия христианских идей и практик, нередко различных трактовок в рамках одной вероучительной системы на становление групповых идентичностей. Так, например, освещается роль исихазма в формировании народной православной духовности и социального поведения, Армянской церкви в консолидации армянского народа, англиканизма и пуританства в их влиянии на складывание современного облика англосаксонского мира.

Наконец, предложенный в издании внеконфессиональный критический исторический анализ вносит вклад в решение не только образовательных и исследовательских задач, но и более масштабных социокультурных задач современного общества: преодоления воинствующего секуляризма и религиозного фундаментализма, различных конфессиональных предубеждений, расширения историко-культурного кругозора, выстраивания гармоничного и плодотворного взаимодействия между Церковью и обществом.

История разных христианских деноминаций рассмотрена в динамике, от момента их зарождения до современности, на основе широкого фактологического материала и в рамках единой концептуальной линии. В центре внимания авторов издания главные вызовы, которые история ставит перед церковным организмом: вероучительные поиски, отношения с государством, соблюдение баланса соборного и персонального как в пространстве вероисповедания и наставления, так и в церковном управлении, защита церковной институции от деструктивного внешнего воздействия и другие. Не отказываясь полностью от хронологического принципа организации материала, авторский коллектив отдал предпочтение тематическому. Основной линией становится историческое развитие организационновероучительного единства христианства: от полного тождества вероучения в условиях разрозненной организационной структуры до прогрессирования дискретности не только в организации, но и в вероучении. 
Четыре книги “Общей истории Церкви” формируют представление об основных вехах развития институционального христианства: 1) формирование Церкви как организационно и вероучительно единой социальной системы (Т. 1. Кн. 1); 2) влияние доктринальных вызовов, возникающих внутри церковного организма, на развитие Церкви как организационносоциальной системы (Т. 1. Кн. 2); 3) влияние организационных вызовов, доктринальные истоки которых находились в церковной системе, на состояние и динамику церковных институций (Т. 2. Кн. 1); 4) влияние секулярного внешнего окружения, стимулирующего развитие синкретических тенденций в обыденном религиозном сознании, на состояние церковных институций (Т. 2. Кн. 2).

Главная идея каждой книги определена вопросом, вынесенным на ее обложку: “Во что, как и где верить, чтобы спастись” (Т. 1. Кн. 1-2; Т. 2. Кн. 1) и “А нужно ли вообще верить?” (Т. 2. Кн. 2). Во введении к первой книге первого тома сформулированы основные определения, применяемые различными отраслями гуманитарного знания по отношению к Церкви, включая богословское определение Церкви как богочеловеческого организма. Тем не менее, в качестве предмета исторического исследования авторы пособия исходят из определения Церкви как специфически христианского социального института.

Раннехристианский период (Т. 1. Кн. 1) осмысливается в пособии как формирование Церкви в качестве социального института, организационной основой которого становятся постепенно осознаваемые и богословски оформляемые вероучительные истины, определяющие смысл христианского учения. Именно они обусловили собой институциональную структуру Церкви как универсальной социальной системы, претендовавшей на объединение в своих границах всего населенного мира, призванного к спасению и богообщению.

Дальнейшее развитие церковной институции в период Средневековья (Т. 1. Кн. 2) ставит в центр изложения вопросы, связанные с развитием церковной ортодоксии и формированием различных отклонений от нее. Внимание читателя концентрируется на догматических расхождениях, которые на всем протяжении рассматриваемого тысячелетия вносили элемент нестабильности в универсалистскую концепцию христианства и привели в организационной сфере к многочисленным церковным разделениям по конфессиональному признаку.

Основной сюжет следующей книги пособия (Т. 2. Кн. 1) - организационный кризис церковной структуры, поколебавший единство не только католического, но и православного (в виде этнофилетизма и автокефализма) мира. Особое внимание уделено феномену экуменизма и его восприятию в западном и восточном христианстве.

Наконец, заключительная книга пособия (Т. 2. Кн. 2) посвящена феномену современного мультиконфессионального христианского мира, столкнувшегося с существенным сопротивлением секулярного общества любым “традиционным” религиозным ценностям - вначале в виде модернизма, затем секулярного глобализма. Одним из результатов этого противостояния стал организационный кризис современного институционального 
христианства, стимулируемый как внешним воздействием, так и некоторыми внутрицерковными процессами.

При изложении истории католицизма авторы отходят от композиционного принципа “истории папства”, который со времен Л. фон Пастора стал превращаться в определенную историографическую доминанту. Основной способ изложения католической проблематики в пособии: рассмотрение в контексте сложной дискуссионной атмосферы нескольких столетий генезиса идеи папской супрематии и ее богословского оформления, а также влияния, которое она оказала на формирование современной организационной структуры Католической церкви. В то же время крайне важным представляется то, что авторы пособия показали сосуществование универсалистских идей с творческим разнообразием поместных традиций (в литургии, праве, народном благочестии, духовной литературе и т.д.).

История поместных православных церквей в пособии охватывает не только греческий, но также славянский, грузинский и румынский ареалы. В “Общей истории Церкви” предложен обзор истории четырнадцати общепризнанных поместных православных церквей, включая Кипрскую, Албанскую, Польскую. Существенным компонентом текста является история мусульманских завоеваний канонической территории восточных патриархатов, изучение процесса автокефализации и взаимодействия поместных церквей в период антиосманских освободительных движений.

Важная черта учебного пособия “Общая история Церкви” - включение в общехристианский контекст истории Русской церкви, несмотря на сложившуюся в российской системе образования традицию разделения истории на всеобщую и отечественную. В подавляющем большинстве случаев учебные курсы и учебники посвящались и посвящаются или “всеобщей истории" (но - вопреки названию - без российской), или только российской. В результате нарушается логика изложения событий, теряется системность, возможность сопоставления процессов, протекавших в России и в других странах. Данное издание носит название “Общая история Церкви” с полным правом, поскольку история Русской церкви присутствует здесь именно в том объеме и там, где это необходимо для воспроизведения общей картины развития. Авторы в разных книгах и темах внедряют отечественный материал в широкий исторический контекст. По мере увеличения мирового значения Русской церкви, от тома к тому растет объем этих параграфов, проводятся сопоставления с реалиями в других православных церквах. Большое место отведено истории старообрядчества, его экклезиологии и его различным направлениям.

Помимо традиционных сюжетов, приковывающих внимание историков, на страницах пособия освещены и малоизученные в отечественной науке события. Например, подробно исследованы процессы формирования, развития и институционального оформления экуменического движения, осмыслено его влияние на современное христианство и роль в организационной структуре секулярной глобализации. Пристально рассматриваются такие проблемы, как сохранение религиозной идентичности в агрессивно настроенном религиозно-культурном окружении, автокефализм, постепенная утрата универсального, вселенского духа православия. 
Целый ряд разделов посвящен вопросам литургики. Авторы вводят в исторический контекст основные литургические понятия, рассматривают изменение их содержания в ходе исторического развития (от богослужения раннехристианских времен вплоть до генезиса современных конфессиональных литургических практик).

Издание снабжено значительным количеством иллюстраций. Приведены не только отсылки к источникам, но и выдержки из них (подчас на языке оригинала или с параллельным переводом). Отдельным достоинством издания является публикация в первой книге первого тома синхронистической таблицы правления архиереев пяти важнейших церковных кафедр (Римской, Константинопольской, Александрийской, Антиохийской и Иерусалимской) от их основания до настоящего времени, соотнесенной с годами правления римских и византийских императоров.

Такой широкий и подробный охват тем, связанных с церковной проблематикой, позволяет использовать “Общую историю Церкви” на семинарских занятиях для сочетания учебного и хрестоматийного текста, а также рекомендовать ее в качестве справочного пособия для более широкой аудитории, чей профессиональный интерес связан с вопросами исторического развития вероисповедания (или религиоведения), церковных институтов, культурных и общественных отношений. 